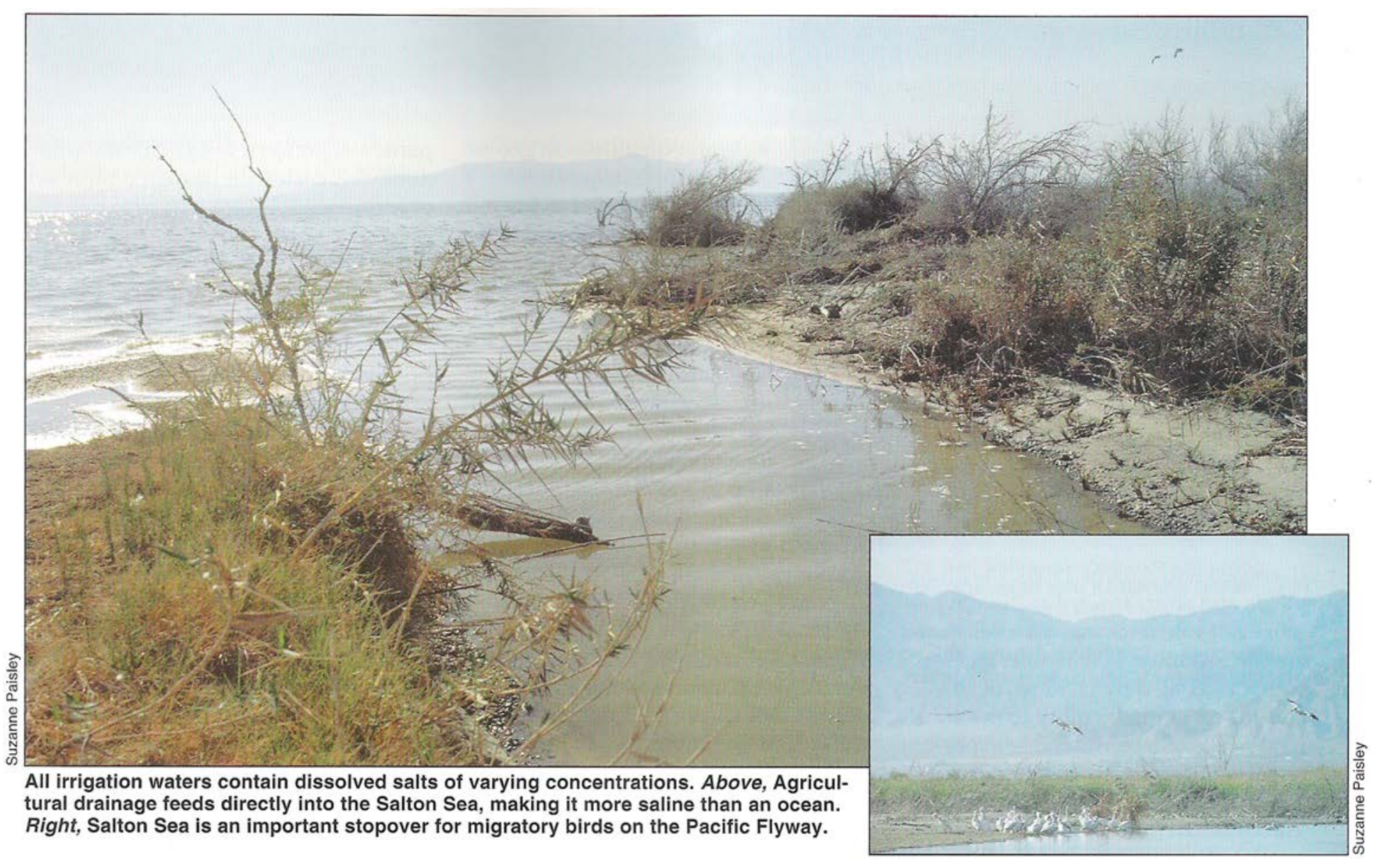

\title{
Soil salinity poses challenges for sustainable agriculture and wildlife
}

John Letey

If soil becomes too saline, crop productivity falls. In California, the Imperial Valley and western San Joaquin Valley are major areas of concern where salinity can harm agricultural productivity. The Imperial Valley has achieved salt balance by discharging salty drainage water into the Salton Sea, but this practice threatens fish and possibly birds. Without an avenue to remove salts from the western San Joaquin Valley, long-term agricultural productivity is jeopardized unless an in-valley sink, such as evaporation ponds, can be used to accumulate the salts. However, high selenium concentrations in drainage-water evaporation ponds can be hazardous to birds. The future of agriculture and wildlife in both valleys can be enhanced by cooperative, innovative approaches between government, growers and environmental advocates. For example, water allocated for agriculture can be used to construct highly productive "compensation habitats," which can attract high concentrations of nesting birds and offset negative impacts to wildlife at the Salton Sea and West Side evaporation ponds.
Tistory has recorded several major 1 Loccurrences of salinity and its effects on society, but the earliest and perhaps most serious occurred during 2400-1700 B.C. in ancient Mesopotamia, now southern Iraq (Jacobsen and Adams 1958). Irrigation projects were developed to deliver water for agricultural production; copious quantities of water were available, leading to increased seepage, flooding, overirrigation and a consequent rise in the water table. Initially, only a few fields were affected, but an increase in the saline levels of fields was recorded between 2100 and 1800 B.C. The Babylonian story of Atrahasis even mentions the "turning white of the fields" 


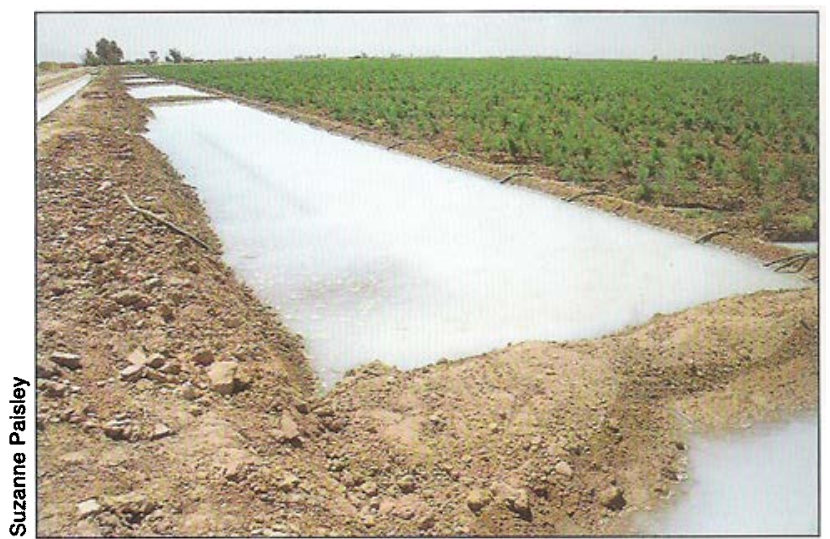

For irrigated agriculture to be sustainable, salt balance must be achleved so that salts added equals salts removed.

(Jacobsen and Adams 1958). Declining yields and shifts toward cultivating more salt-tolerant crops paralleled increasing salinity. Meanwhile, cities were devastated by yield reductions, and the resulting inability to meet the food needs of a considerable superstructure of priests, administrators, merchants, soldiers and craftsmen. The southern part of the alluvial plain never recovered and many great Sumerian cities dwindled into villages or were left in ruins.

The story of Mesopotamia is ancient, but it could be repeated in California. Approximately 4.5 million acres of irrigated cropland - primarily on the West Side of the San Joaquin Valley - are affected in California by saline soils or saline irrigation water. Predictions vary for the rate at which salinization is occurring, but tens of thousands of productive agricultural acres are clearly at risk (CAST 1996).

Irrigation in semiarid regions such as California invariably leads to soil salinization unless mitigated by appropriate management.

Three factors contribute to salinization:

- All irrigation waters contain dissolved salts, with concentrations varying considerably according to the origin of the water.

- Plants extract negligible amounts of salt, so the soil solution becomes concentrated as water is removed by evapotranspiration.
- Water quantities in excess of evapotranspiration must be applied to leach salts beyond the root zone to prevent reduced crop yields.

Saline water leaving a plant's root zone may also percolate down until it reaches groundwater, resulting in degraded water quality. Or, it may migrate and seep to a lower land surface. When the latter occurs, the seepage area becomes salinized as water evaporates and the salts concentrate.

Water percolating below the root zone can cause the water table to rise. Without the ability to leach salt from the root zone, concentrations rise to detrimental levels. Additionally, high water content interferes with the oxygen supply to the roots, resulting in further crop damage. When a water table reaches the root zones, yields can be sustained only by draining to remove excess salt, water and other dissolved compounds.

Sustainable irrigated agriculture in areas where salinity poses a problem can be achieved by adhering to two basic principles: (1) salt balance, defined as salts removed must equal salts added, must be achieved, and (2) systems must be installed to remove drainage water and dissolved salts when the water table reaches the root zone. These principles can be applied on a field, farm or regional basis.

Most surface-water supplies in California are relatively low in salinity. Indeed, some irrigation waters derived predominantly from snowmelt and rainwater from the Sierra Nevada contain extremely low concentrations of dissolved salts. In contrast, irrigation water from the Colorado River is the most saline. Irrigation water pumped from wells varies considerably in salinity, depending upon the geologic strata from which it is extracted.

Although salinity is a concern in isolated areas, the Imperial Valley and the western San Joaquin Valley are of particular concern to agricultural productivity, each with its own unique set of features.

\section{Imperial Valley and Salton Sea}

The Imperial Valley, located in southeast California, has a hot desert climate, allowing some agricultural productivity year-round. Very little precipitation occurs, and the evapotranspiration rate is high. An elaborate irrigation and drainage system has been implemented in the Imperial Valley. Crops are irrigated with Colorado River water and drainage water is then discharged into the Salton Sea, which is fed predominantly by this source. The 35-mile-long, 15-mile-wide sea initially came into existence when, at the turn of the 20th century, Colorado River waters were diverted to the flood-prone region for agriculture. An irrigation canal subsequently broke and flooded the basin for 2 years.

While those waters would have evaporated years ago, the sea has since been fed by drainage water, sewage and other sources of water. With no outlet, the Salton Sea's salinity has continuously increased as the water evaporates.

The Salton Sea area serves as an important link on the Pacific Flyway, North America's West Coast route for migrating birds. The sea and adjacent wetlands, rivers and croplands provide foraging and nesting for more
Agriculture has a bistory of increasing productivity per unit of land area so that a growing human population can be fed without large expansions of acreage. Attention should now be directed to- ward increasing wildlife production per unit of babitat area. 
than a million birds. In general, the highest avian use occurs in the southern and northern portions of the sea where the waters flow in (Salton Sea EIS/EIR 1999). In recent years, the sea has been plagued by massive bird and fish die-offs. The bird deaths have been attributed to a variety of agents, including avian cholera, Newcastle disease, avian botulism and salmonella. The fish deaths are generally associated with oxygen depletion, which is caused by high levels of nutrients in the sea. So although the salinity of the sea has been rising and is presently more concentrated than an ocean, salinity has contributed little, if any, to the previous fish and bird deaths. Nevertheless, if salinity is allowed to increase it will eventually be too concentrated to support fish.

Restoring the Salton Sea to its "glory" of the 1960s has received considerable public and political attention. The Salton Sea Reclamation Act of 1998 (H.R. 3267), established a structure for determining the kind of project necessary to achieve restoration of the sea. The five characteristics most frequently identified as components of a "saved" Salton Sea are (1) continued use as an agricultural sump; (2) stabilization of elevation; (3) control of salinity levels; (4) elimination of preventable fish and bird deaths; and (5) enhancement of water-based recreational activities, particularly sport fishing. The U.S. Bureau of Reclamation and the Salton Sea Authority are the lead agencies working to identify potential restoration alternatives, and a subcommittee was established to investigate the scientific basis for a restoration project.

On Jan. 13, 2000, the U.S. Department of Interior released a rescue plan for the Salton Sea. Despite the five identified components of a "saved sea," the present plan focuses primarily on stabilizing salinity. The draft environmental impact statement presented five options from which one will be selected after a 90-day public comment period. Proposed approaches included the construction of evaporation ponds within the sea to concentrate the salts, and/or construction of an enhanced evaporation system (EES). The EES involves spraying water into the air to promote evaporation and dispersion of salts to the ground. Some consider the focus on salinity to be too narrowly restrictive (Cohen et al. 1999).

The studies commissioned by the science subcommittee reached several findings especially pertinent to agriculture: Pesticides and selenium were either not detected or detected at very low concentrations in the sea, and plant nutrient concentrations from agricultural and sewage drainage water in the seawater and sediments are relatively high and contribute to episodes of oxygen depletion. Since the present restoration goal is to stabilize the sea's salinity, the draft environmental impact statement concluded that farmland and its productivity would not be significantly affected by the proposed restoration actions.

\section{Western San Joaquin Valley}

Irrigation water has contributed to the western San Joaquin Valley's high agricultural productivity. Although salt concentrations in the imported water are relatively low, 1.9 million metric tons of salts are imported each day from irrigation water and other sources (equivalent to 57 railroad cars of salt). Furthermore, the region's soils are derived from alluvium originating from the coastal mountains; since the mountains were once below sea level and uplifted to their present state, the alluvium contains high concentrations of salts and elements typical of a marine environment.

The need for a drainage system to export salts from the West Side was apparent when the irrigation projects were initiated during the $1950 \mathrm{~s}$ and 1960s but a number of political, eco-
The San Luis Drain began transferring drainage water into Kesterson Reservoir in 1981. A few years later, high concentrations of selenium were linked to bird deaths and deformities. Water is carefully managed now to minimize wildife impacts.

nomic and other factors interfered with construction. In 1975, the Interagency Drainage Program (IDP) was organized with the combined efforts of the U.S. Bureau of Reclamation, California Department of Water Resources and California State Water Resources Control Board, to plan "a drainage program that can overcome the hurdles that caused previous efforts to falter." The IDP report in 1979 recommended staged construction of a drain between Kern Lakebed and Suisun Bay, establishment of 64,300 acres of wetland habitat, a cost-sharing and repayment arrangement, and a series of studies used to develop the technical analysis for the State Water Resources Control Board waste-discharge permit.

In 1981, drainage water began flowing through the initial 82-mile segment of the San Luis Drain between Laguna Avenue in southern Fresno County and Kesterson Reservoir. The drain was to serve as a wildlife habitat and temporary water-holding facility until the second stage of the drain was completed. But bird deaths and deformities were observed at the reservoir by 1982 and 1983, and later attributed to high concentrations of selenium in the drainage water, which are toxic to birds. The end result was closure of 


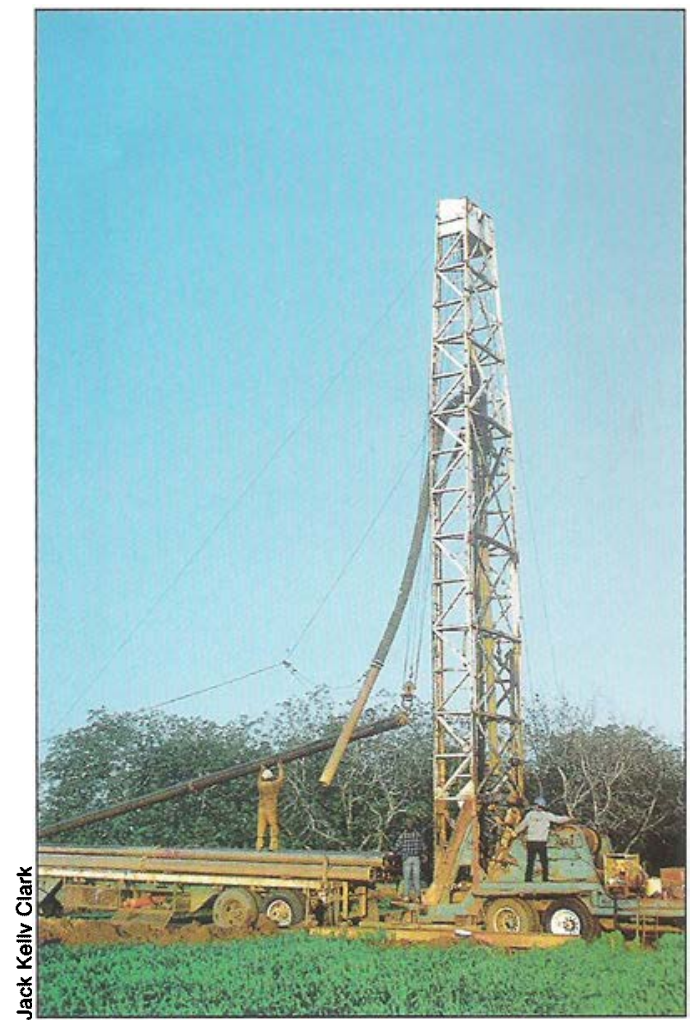

Alternatives to deal with the salinitytoxics-drainage problem in the San Joaquin Valley include source control, groundwater management, drainage-water reuse, water treatment and off-site disposal.

Kesterson Reservoir and plugging of drain lines in the Westlands Water District that were contributing drainage flows to the reservoir (Letey et al. 1986).

Subsequently, three federal agencies (Bureau of Reclamation, Fish and Wildlife Service and Geological Survey) and two California resource agencies (Department of Water Resources, and Fish and Game) jointly established a San Joaquin Valley Drainage Program in 1984. The goal of the program was to develop short- and long-range plans for solving the salinity-toxicsdrainage problems of the western San Joaquin Valley.

Constraints were placed on the development of the plans. Specifically, all alternative plans must meet California's water-quality objectives, and focus on in-valley solutions (San Joaquin Valley Drainage Program 1990). The latter constraint eliminated the option of completing the drain as originally planned or any other disposal to a bay or the ocean. These constraints made it all the more difficult for the West Side to achieve salt balance.

\section{Assessing the alternatives}

Several management options have been proposed to deal with the salinitytoxics-drainage problem in the San Joaquin Valley. Eight technical committees (comprised of individuals from UC, federal and state agencies, and the private sector) recently synthesized the present state of knowledge concerning the following options into a series of reports (San Joaquin Valley Drainage Implementation Program 1999).

Source control. Source control requires the farmer to apply water uniformly across the field and accurately control the volume applied. Farmers can gain greater control by switching from surface irrigation to sprinklers to microirrigation systems, thereby reducing the volume of drainage water and subsequent costs to dispose of it. Growers must carefully evaluate the tradeoffs between the increased costs associated with source control - such as, for example, installing microsprinklers and the benefits associated with lower costs for water and drainage disposal.

Groundwater management. A rise in water-table elevations results from an imbalance between the water application (irrigation and precipitation) and water extraction (crop evapotranspiration and pumping). Groundwater management entails increased pumping for irrigation to lower the water table and reduce drainage volume. During drought years, farmers have pumped more to compensate for reduced surface-water supplies, and in turn lowered water tables. In principle, this practice could be continued during years of plentiful surface-water supplies. However, its success requires coordinated regional management and compliance. A long-term consequence is that pumping accelerates the exploitation of high-quality groundwater. Rather than discharging salts and chemicals through drainage systems, the chemicals move downward with the water toward the zone from which the water is pumped. Pumping increases the rate at which good quality water is replaced by poor quality water.
Land retirement. Fields can be removed from agricultural production and converted to other uses, releasing the irrigation waters for other uses. As a voluntary program, growers with high water tables and low agricultural productivity would be most likely to agree to retire their land. These farms are likely to be located in lower elevations near the trough of the West Side, which could receive lateral flows from up-slope irrigation. A negative consequence is the probability that with a high water table, water will migrate to the soil surface by capillary action, transporting and depositing salts and toxic elements. The resulting landscape would be sparsely vegetated, promoting erosion and degrading wildlife habitat.

Drainage water reuse. While drainage water may be reused for irrigating salt-tolerant crops, even those have upper limits and leaching of salts from the root zone will be required. Indeed, if irrigation waters are very saline, relatively high leaching fractions may be required because salts are placed back into the soil and salt balance is not achieved. A hazard of using drainage water for irrigation is the destruction of the soil's physical properties, threatening the viability of agriculture. For example, crust can form on the soil surface resulting in poor infiltration, which in turn impedes leaching of salts and promotes their accumulation in the soil. Amendments such as gypsum can mitigate physical deterioration of the soil but are costly to the farmer.

Water treatment. Water can be treated to remove total salinity and selenium. Reverse osmosis (RO) is the most promising treatment technology, but is constrained by high cost and difficulties with safe disposal of the brine. The value of treated water could offset some of the treatment costs, and a water trade with the urban sector, which can afford to pay more for water, could enhance the feasibility of RO treatments.

Treating drainage water to remove only selenium would still leave a very saline water. Nevertheless, it would increase the options for disposing of 
the drainage water with less ecological damage. Several laboratory investigations have demonstrated that bacteria can effectively reduce selenium, but this has not been adequately demonstrated in field tests (San Joaquin Valley Drainage Implementation Program 1999). Because selenium removal reduces hazards to wildlife but otherwise does not materially increase the monetary value of the water, costs for selenium treatment cannot be offset by the production of a more valuable water. Selenium concentrations can also be reduced in open systems such as flow-through wetlands, but this solution can also pose hazards to wildlife. The benefits of treated water to wildlife must be weighed against the potential exposure of birds to toxicity associated with a flow-through system.

Off-site disposal. Salt balance on the West Side cannot be achieved without out-of-valley disposal. Unfortunately, this option has not undergone scientific scrutiny concerning its ecological or economical viability. Such disposal is not available now, nor will it be in the immediate future. However, a decision by the U.S. Court of Appeals for the Ninth Circuit filed Feb. 4, 2000, (Firebaugh Canal Co. vs. USA, 95-15300) states that "the Government must act promptly to provide drainage service." In the case, several Central Valley water districts challenged the U.S. Bureau of Reclamation's historic failure to provide for drainage facilities in California water contracts. The decision allows for a range of options to remove drainage water from the West Side, and does not rule out something other than the San Luis Drain. The means by which the Bureau will comply with this decision was uncertain at the time of this writing.

Evaporation ponds. The only way to sustain agricultural production is to separate salts from productive agricultural lands. Even though there cannot be salt balance in the San Joaquin Valley without a means for salt disposal outside the valley, growers can balance salt on individual fields. Evaporation ponds are an option that perma-

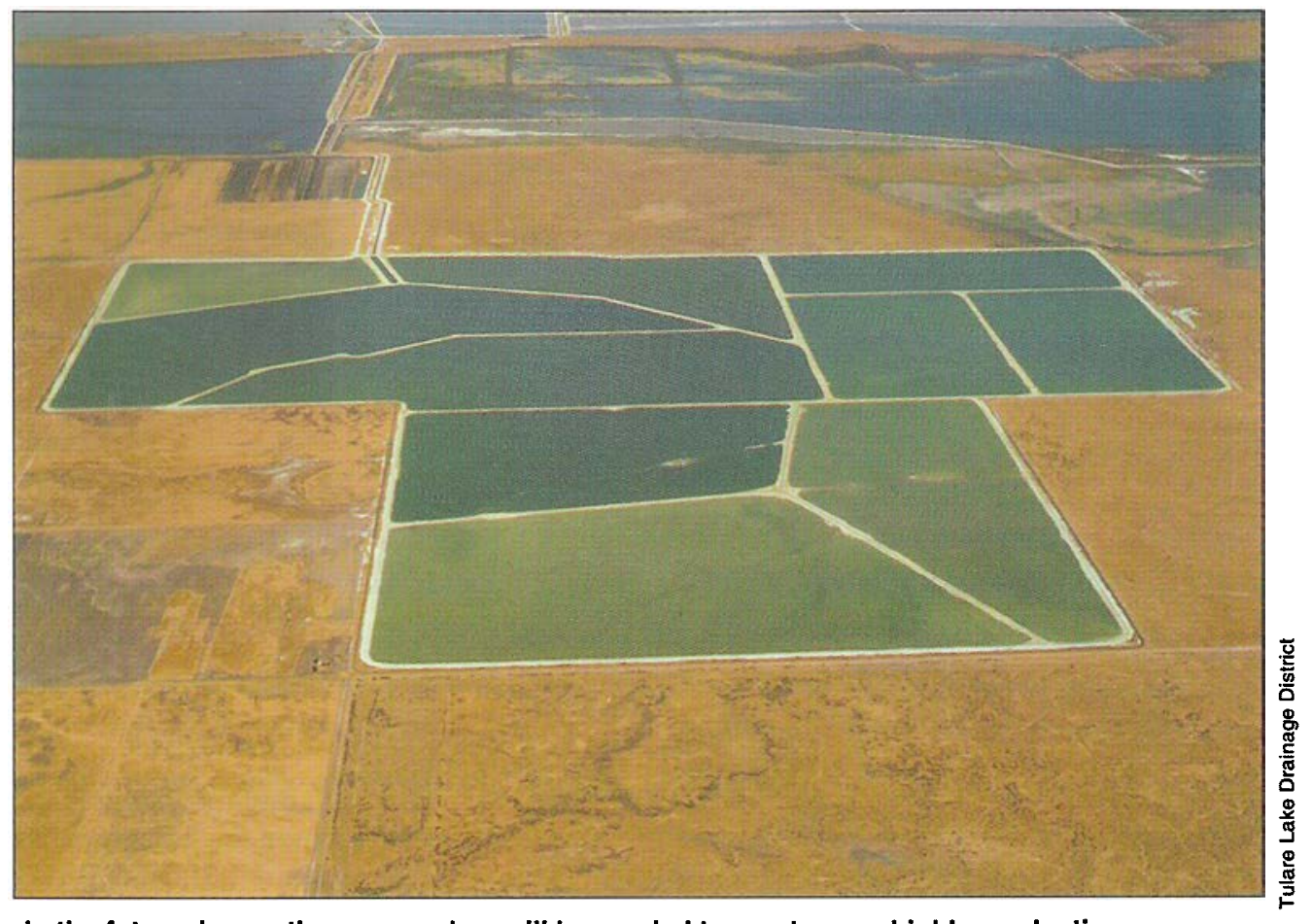

In the future, Innovative approaches will be needed to create new, highly productive habitat for wildlife in agricultural regions. At Tulare Lake Drainage District, a compensation habitat was constructed on about 307 acres to mitigate for bird losses on 2,900 acres of evaporation ponds, above.

nently removes salts from productive farmland and accumulates them on land selected for a pond; long-term removal of the salts is another issue that must be resolved. Unfortunately, selenium in evaporation ponds creates a significant bird hazard. A number of steps can be taken to reduce impacts to birds, including making the ponds less attractive to birds, using various methods to scare them away, disrupting the selenium food chain, and reducing selenium concentrations by flowing water through constructed wetlands prior to discharge into the evaporation ponds. A combination of such methods can greatly reduce impacts on birds, but it would be virtually impossible to design a system that is completely bird-safe.

Compensation habitat. Recent studies demonstrate that compensation habitat can be designed and operated successfully to support high densities of nesting wild birds. For example, Tulare Lake Drainage District (1999), which has 2,900 acres of evaporation basins, constructed compensation habitat on 307 acres. The habitat is designed to be attractive to birds, while evaporation ponds are managed to discourage them. In 1994, before compensation habitat was constructed, there were approximately 2,200 nest starts on evaporation basins. In 1999, there were approximately 4,100 nest starts on the compensation habitat, and only about 200 on the evaporation basins. Compensation habitat can effectively increase bird populations. A policy driven by the goal of enhancing bird numbers to compensate for the risk of bird damage increases management options to sustain high agricultural productivity.

\section{Future in focus: Creatively managing salt}

The dilemma of dealing with salinity in irrigated regions has historical roots dating back to Mesopotamia and 2400 B.C. In 21st-century California, long-term agricultural sustainability will also require salt balance on irrigated farmlands. The salt balance can be viewed regionally, with all salts introduced to a valley leaving the valley, or on a more localized scale, whereby all salts entering the field must leave the field by some environmentally acceptable means.

Salt balance can be achieved in the Imperial Valley by using the Salton 


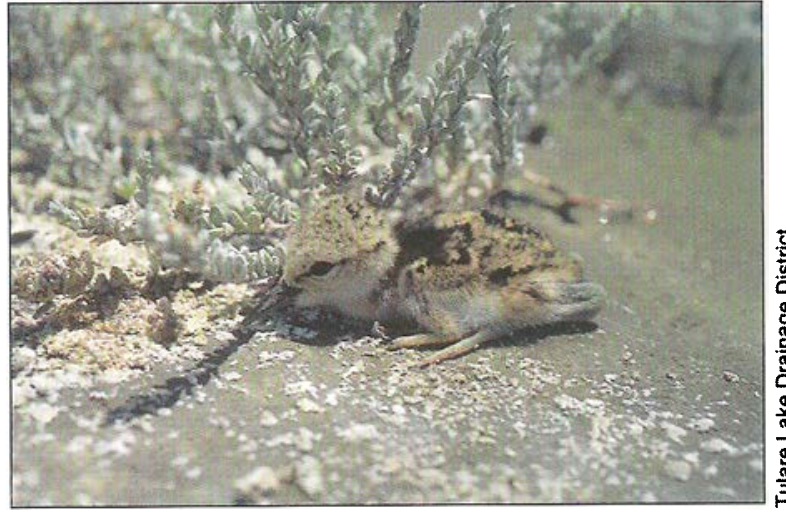

In 1994, there were 2,200 nest starts on evaporation ponds at Tulare Lake Drainage District. In 1999, 4,100 birds started nests on the compensation habitat and 200 on the ponds.

Sea as a salt repository, but this will ultimately cause fish to die. The extinction of fish in the sea is unacceptable to a significant segment of society. Therefore, some costly Salton Sea restoration projects are being considered. The survival of agriculture is somewhat protected by the fact that if agriculture does not provide water to it, the sea will dry up.

The future of agriculture in the Imperial Valley will more likely be constrained by the availability of irrigation water than by salinization. A likely scenario is that as urban water demands increase and water supplies diminish, more water transfer arrangements will occur between farmers and cities, similar to the recent agreement between Imperial Valley and San Diego. With reduced irrigation, less agricultural water will flow to the Salton Sea and the sea will shrink.

The future of agriculture in the western San Joaquin Valley is more problematic. Selenium in the drainage water greatly limits the options for its disposal. Achieving salt balance by removing the salts from the West Side is at best a distant possibility. Salt balance within a field requires placement of salts in a repository, and evaporation ponds can serve that purpose. However, the potential for bird damage on evaporation ponds remains a constraint; indeed, California's Regional Water Quality Control Boards have been limiting their use and construction due to bird impacts.

Regulations will drive the future of agriculture on the West Side. A policy directed toward maximizing bird populations through sompensation habitat and other means, while allowing o some bird damage, would enable growers to use a combination of drainage-disposal methods to sustain agriculture.

Numerous federal, state and private agencies share responsibility for the management of salinity in the San Joaquin Valley. None, however, has the authority or capability to assume unilateral leadership. To some extent these agencies have conflicting interests, so achieving consensus can be difficult and challenging. Productive farmlands are going out of production because of high water tables and the inability to dispose of drainage waters. In the future, the amount of productive agricultural land is likely to diminish, and acreage with water tables approaching the surface are in greatest jeopardy. All of the options discussed can minimize and slow the salinization process, but none will completely solve the problem unless an out-of-valley discharge solution becomes feasible.

The future of both agriculture and wildlife in the Imperial and western San Joaquin valleys can be enhanced by cooperative rather than adversarial approaches by agricultural and environmental advocates. In the Imperial Valley, agricultural drainage waters could be used to create productive wildlife habitat prior to discharge into the Salton Sea. Drainage waters can sustain wildlife before terminating at the sea, where the chemicals accumulate and concentrate (UC MEXUS 1999). Indeed, high numbers of birds are presently observed in areas adjacent to the sea's main body. In the western San Joaquin Valley, growers can create a productive wildlife system by mitigating evaporation-pond damage and constructing alternative and compensation habitat.

In both cases, some habitat will be sacrificed - the evaporation ponds and the main body of the Salton Sea.
This approach requires a new paradigm, whereby wildlife habitat is not limited to "natural" systems. It calls for innovative approaches to creating new, highly productive habitats. Agriculture has a history of increasing productivity per unit of land area so that a growing human population can be fed without large expansions of acreage. Attention should now be directed toward increasing wildlife production per unit of habitat area. Such an approach can benefit both wildlife and agriculture in the Imperial Valley and western San Joaquin Valley.

J. Letey is Distinguished Professor of Soil Physics, UC Riverside, and Director of the UC Center for Water Resources, and Salinity and Drainage Program.

\section{References}

[CAST] Council for Agricultural Science and Technology. 1996. The Future of Irrigated Agriculture. Task Force Report No. 127. Ames, IA. 76 p.

Cohen MJ, Morrison Jl, Glenn EP. 1999. Haven or Hazard: The Ecology and Future of the Salton Sea. Pacific Institute. Oakland, CA. 63 p.

Jacobsen T, Adams RM. 1958. Salt and silt in ancient Mesopotamian agriculture. Science 128: 1251-8.

Letey J, Roberts C, Penberth M, Vasek C. 1986. An Agricultural Dilemma: Drainage Water and Toxics Disposal in the San Joaquin Valley. UC Agricultural Experiment Station Spec. Publ. 3319.56 p.

[Salton Sea EIS/EIR] Salton Sea Restoration Project Environmental Impact Statement Environmental Impact Report. 1999. www.lc.usbr.gov.

San Joaquin Valley Drainage Implementation Program. 1999. Technical committee reports: drainage reuse, drainage treatment, land retirement, evaporation ponds, source reduction, groundwater management, river discharge, salt utilization, grasslands subarea, Tulare/Kern subarea. Division of Planning and Local Assistance, Dept. of Water Resources, Sacramento, CA. wwwdpla.water.ca.gov/agriculture/drainage/ implementation/hq/sjvlib.htm

San Joaquin Valley Drainage Program. 1990. A Management Plan for Agricultural Subsurface Drainage and Related Problems on the Westside San Joaquin Valley. Final Report. 183 p.

Tulare Lake Drainage District. 1999. Activity Summary. Corcoran, CA. 40 p.

UC MEXUS. 1999. Alternative Futures for the Salton Sea. UC Riverside Salton Sea Project Steering Committee. $23 \mathrm{p}$. 